University at Buffalo School of Law

Digital Commons @ University at Buffalo School of Law

$12-1-2012$

\title{
Piety and Profession: Simon Greenleaf and the Case of the Stillborn Bowdoin Law School, 1850-1861
}

Alfred S. Konefsky

University at Buffalo School of Law

Follow this and additional works at: https://digitalcommons.law.buffalo.edu/journal_articles

Part of the Jurisprudence Commons, and the Legal Education Commons

\section{Recommended Citation}

Alfred S. Konefsky, Piety and Profession: Simon Greenleaf and the Case of the Stillborn Bowdoin Law School, 1850-1861, 85 New Eng. Q. 695 (2012).

Available at: https://digitalcommons.law.buffalo.edu/journal_articles/811

Originally published 85(4) The New England Quarterly 695-734 (Dec. 2012). @ 2012 by The New England Quarterly.

\section{IN COPYRIGHT}

This Article is brought to you for free and open access by the Faculty Scholarship at Digital Commons @ University at Buffalo School of Law. It has been accepted for inclusion in Journal Articles by an authorized administrator of Digital Commons @ University at Buffalo School of Law. For more information, please contact lawscholar@buffalo.edu. 


\section{Piety and Profession: Simon Greenleaf and the Case of the Stillborn Bowdoin Law School, 1850-1861}

ALFRED S. KONEFSKY

$I^{N}$

$\mathrm{N}$ 1850, a small college in Brunswick, Maine, made a surprising decision: it began to explore the possibility of establishing a school of law. The venture was remarkable on a number of grounds, not least of which was the rather dismal record at midcentury of similarly ambitious proposals. Yale's law school, which emerged from a private, proprietary school in the 1820s, did not grant degrees until 1843, and Yale "seriously considered dissolving the school” in 1845 and again in 1869 .

I thank Barry Sullivan and Winni Sullivan for their helpful readings of the article and Dianne Avery for her thorough and careful editorial and substantive suggestions. The usual disclaimer as to final responsibility applies. Permission to publish from manuscript sources has been generously granted by the following manuscript collections: Bowdoin College Archives, Brunswick, Maine; The Huntington Library, San Marino, California; Historical Society of Pennsylvania, Philadelphia; Brown University Archives, Providence, Rhode Island; Harvard Law School Library, Cambridge, Massachusetts; and Heidelberg University Library, Germany. I am particularly grateful to Edwin Moloy, curator of modern manuscripts and archives, and Lesley Schoenfeld, access services coordinator, for assistance with the Simon Greenleaf Papers in the Special Collections Department of the Harvard Law School Library, as well as to Karen Beck, Manager, Historical and Special Collections, Harvard Law School Library, for arranging to reduce into a digital format the draft of Greenleaf's report on establishing a law school at Bowdoin College. Richard H. F. Lindermann, director of the George J. Mitchell Department of Special Collections and Archives at the Bowdoin College Library, offered prompt and indispensable guidance to the collections under his supervision. And Olga Tsapina, Norris Foundation Curator of American Historical Manuscripts at the Huntington Library; Hilary S. Kativa, rights and reproductions associate at the Historical Society of Pennsylvania; Jennifer J. Betts, University Archivist at the John Hay Library, Brown University; and Dr. Karin Zimmermann, Heidelberg University Library, were all courteous and responsive in helping me navigate their collections.

The New England Quarterly, vol. LXXXV, no. 4 (December 2012). (C) 2012 by The New England Quarterly. All rights reserved. 
Princeton's law school, established in 1846, "was shuttered in 1852." Harvard Law School traced its founding to 1817 , but at that point it was little more than a law professorship. Reduced to a single student by 1829 , it was revived under the leadership of Joseph Story and Simon Greenleaf in the 1830s and 1840s, an effort substantially assisted by Nathan Dane, who had funded the creation of an endowed professorship to be held by Story. ${ }^{2}$ And in the early 185 os, Brown University explored and then rejected the idea of founding a law school as part of the searching curricular reform of its president, Francis Wayland. In this inhospitable environment, Bowdoin College, chartered in 1794 , embarked on its rather quixotic mission.

By the mid-nineteenth century, the primary modes of delivering a legal education in the United States-law office apprenticeships, undergraduate university law professorships, and private, proprietary law schools_-seemed ripe for reform, and yet university legal education did not thrive during this period. Therefore, the rising hopes for a law school at Bowdoin College and their ultimate frustration are significant not only as an episode in the history of legal education, or of education more broadly, but for what they reveal about the state of the legal profession and the science of the law in antebellum America. At the center of this inquiry is Simon Greenleaf (1783-1853), who had retired from Harvard in 1848 , having served first as Royall Professor of Law and then, succeeding Story, as Dane Professor. Greenleaf had maintained a connection with Bowdoin College for nearly forty years. In $185^{\circ}$, he was in the middle of his second term as a member of Bowdoin's board of overseers, his first term $\left(\mathbf{1 8 1 5 ^ { - 2 } 8 )}\right.$ having coincided with

\footnotetext{
${ }^{1}$ John H. Langbein, "Blackstone, Litchfield, and Yale: The Founding of the Yale Law School," in History of the Yale Law School: The Tercentennial Lectures, ed. Anthony T. Kronman (New Haven: Yale University Press, 2004), p. 17. Not all ventures failed, but the odds of success for a small college would have been long. For a chronological list of law schools affiliated with a college or university, and a corresponding tracking of their dates of failure during this period, see Alfred Z. Reed, Training for the Public Profession of the Law (New York: Carnegie Foundation, 1921), pp. 421-30.

${ }^{2}$ Reed, Training for the Public Profession of Law, pp. 137-40, 142-5o. See also Charles Warren, History of the Harvard Law School, 3 vols. (New York: Lewis Publishing Co., 1908), 1:304-15, 333-35, 338-70, 413-61, 480-506, and 2:1-46.
} 
his law practice in Maine. ${ }^{3}$ In the years between his terms of service to the college, Greenleaf had occasionally offered Bowdoin legal advice. In the early 1830 , he represented college president William Allen in a legal dispute that was Bowdoin's version of the Dartmouth College case, and in the early 1840 s he helped the college assert its property interests in regard to James Bowdoin's estate, a move important to the school's financial security, if not its very survival. ${ }^{4}$

Greenleaf was, then, an obvious choice to advise Bowdoin on its proposed law school. Over the course of almost two years, the college would court his opinion and his participation. From that relationship emerged a unique document, a report in which Greenleaf distilled his ideas about the proper form and function of a law school, a record that is a valuable source for understanding not only the educational and legal challenges of the decade before the Civil War but of its social, political, and religious complexities as well.

\section{$\sim$}

In late January $185^{\circ}$, Greenleaf wrote to Leonard Woods Jr., who had replaced the unpopular William Allen when he resigned the presidency of Bowdoin in 1839 . "Since you mentioned to me the subject of a Law Department in Bowdoin College," Greenleaf began, "it has occurred to me that a very valuable addition to the Law \& Political alcoves in the College Library might be made." With few exceptions, the library collections of practicing lawyers were meager and haphazard. One of the primary attractions of academic legal study was that colleges and universities could systematically stock their library shelves with the increasing supply of legal texts_-statutes,

\footnotetext{
${ }^{3}$ General Catalogue of Bowdoin College and the Medical School of Maine, 17941894 (1894), p. 9. In 1817, the college granted Greenleaf an honorary A.M. (p. 146).

${ }^{4}$ See Louis C. Hatch, The History of Bowdoin College (Portland, Me.: Loring, Short and Harmon, 1927), pp. 74-82, 109-11. Trustees of Dartmouth College v. Woodward, decided by the U.S. Supreme Court in 1819, upheld the enforceability of the school's original charter under the contract clause of the federal constitution against an attempt by the New Hampshire legislature to alter its terms.
} 
reports, periodicals, and treatises—and, thus, markedly improve upon the education available in office apprenticeships. Such an undertaking was, however, costly, particularly at an institution like Bowdoin, which had been plagued with financial problems since the Panic of 1837. But at Harvard, Greenleaf had pursued an effective strategy, which he now recommended to Woods. He explained, "You are aware that several States are in the habit of mutual exchange of their respective statutes \& legislative documents, \& that not infrequently they send duplicates \& even triplicates to each other. Congress, also, sends its laws \& documents, with equal liberality, to the States. With the knowledge of these facts, I procured the passage of a Resolve, directing the Secretary of State \& Librarian to deposit in the Law Library of Harvard University one copy of all the State \& National laws \& documents in the State library \& council chamber, of which the State possessed more than one copy; \& to continue to do so in future. . . . I presume that by virtue of this resolve, the Law Library gained from 500 to 1000 volumes."5

In early March, Woods launched his appeal to Greenleaf. Woods had "recently visited the Kennebec \& the Penobscot, and ... conversed with many of our public men, of the legal profession and others, and have heard a uniform desire expressed for the establishment of a Law School in the State, to counteract the downward tendencies of the profession." These interested individuals had expressed, Woods told Greenleaf, "a uniform opinion that nothing but your name would be necessary to ensure an adequate number of students, in any part of the country, especially in this State." And, the president concluded, "I cannot but hope that this great \& new field of influence and usefulness, together with the prospect of

5 Simon Greenleaf to Leonard Woods Jr., 30 January $185^{\circ}$, Leonard Woods Administrative Records (1.2.4), Bowdoin College Archives, Brunswick, Maine. For the collections likely to be held by antebellum practicing lawyers, see Michael H. Hoeflich, Legal Publishing in Antebellum America (New York: Cambridge University Press, 2010), pp. 33-42, and his "Introduction: Justice Joseph Story and His Library," in The 1846 Auction Catalogue of Joseph Story's Library (Austin: Jamail Center for Legal Research, the University of Texas at Austin, 2004), pp. 7-11. 
your daughter's coming to Brunswick, may incline you to think favorably of this object, and that with your consent, it may be made a topic of deliberation, if not of action, at the coming meeting of the Boards." ${ }^{6}$

Responding ten days later, Greenleaf was cordial but direct. "I very sensibly feel the kindness which has connected my name with that proposed department [the law school]. Under other circumstances, I should be very much gratified with such a relation to the college; but in my present situation, it would not be in my power to entertain the proposal, \& it would therefore be superfluous for the corporation to make it." Speaking as a member of the corporation, however, he offered Woods the benefit of his experience in university legal education

to suggest one or two things in my mind on that subject. It would seem necessary, in the first place, to raise funds, sufficient to secure, at all events, a considerable portion, if not the whole, of the professor's salary. For the small amount of fees derived from students will all be required for the augmentation of the Law Library, \& the discharge of incidental expenses, at least for two or three years. Should the School increase, another professor will be needed, for service one half, or more, of the year. In connexion with the raising of funds, an effort should be made to provide a Law Library. Something may be done in this way by soliciting donations of books from members of the profession, \& of monies also, from individuals; but the main reliance, I think, must be ultimately upon the tuition fees. In this connexion permit me to remind you of the application to the legislature, which I mentioned in a recent letter.

In conclusion, Greenleaf reassured Woods that he would "be happy to be of service in this matter, in any way in my power"; but he reiterated that he "probably shall never be able to discharge the duties of a Law Professor again, unless for a

\footnotetext{
${ }^{6}$ Woods to Greenleaf, 4 March 185o, Simon Greenleaf Papers, Special Collections, Harvard Law School Library. One of Greenleaf's daughters, Caroline, was married to Andrew Croswell, at that time rector of St. Paul's [Episcopal] Church in Brunswick. See James Edward Greenleaf, Genealogy of the Greenleaf Family (Boston: F. Wood, 1896), pp. 144-45.
} 
few months in the summer; \& not at all during the present year."7

Perhaps Woods thought that Greenleaf had left the door open, if only slightly. In any case, as Woods continued to investigate the possibility of a law school at Bowdoin, he gave little or no indication that Greenleaf had declined the offer of a full-time professorship. Woods may, of course, have believed that the project would not be supported unless Greenleaf were associated with it. In mid-May 1850, John Tenney, an 1816 graduate of Bowdoin, an associate justice of the Supreme Judicial Court of Maine (he would become chief justice in 1855), and a trustee of Bowdoin who had only recently left the board of overseers, replied to Woods's inquiry requesting his views on the proposed law school. The authors of the earliest history of Bowdoin (who, one suspects, knew him) described Tenney as "a man of large frame. His intellect was solid rather than imaginative, and if somewhat slow was remarkably strong and sure." His letters on the subject of the proposed law school confirm that assessment: they are ponderous, cautious, and unoriginal.

Tenney divided his initial letter to Woods into four parts. First, he examined Maine's economic and legal circumstances. "The extensive and various resources of this State, with its great waterpower and its numerous harbors upon a long line of seacoast, hold out superior inducements to agriculture, manufacturing and commercial enterprise. An industrious and intelligent people are already engaged in developing these resources, and making use of these natural advantages. Their numbers,

\footnotetext{
${ }^{7}$ Greenleaf to Woods, 14 March 1850 , Woods Administrative Records (1.2.4). This was not the first time that Greenleaf was associated with an attempt to establish a law school in Maine. In 1832, shortly before he left Maine to join Story at the Harvard Law School, Greenleaf and his friend and fellow Portland attorney Stephen Longfellow (father of Henry Wadsworth Longfellow) jointly advertised the founding of a law school in Portland. See the advertisements dated "Portland, Sept. 3, 1832," published in the Portland Advertiser of 15 and 20 September 1832 . This episode seems to have escaped historical attention, and there is no evidence that the law school in Portland ever opened.

${ }^{8}$ Nehemiah Cleaveland and Alpheus Packard, History of Bowdoin College (Boston: J. R. Osgood and Co., 1882), p. 191.
} 
and their means to prosecute further these purposes[,] are annually increasing." This progress had ramifications for the legal system. "Many important contracts must necessarily be made and business transactions occur in such pursuits. In the inception of these transactions legal advice will be more or less needed and sought after, and disputes ending in litigation will undoubtedly arise from the business in which our citizens will be extensively engaged." 9

In short, Maine needed a competent cohort of lawyers, but at present its bar did not compare favorably with those of other states. "Owing to some injudicious legislation touching the admission of attorneys to the Bar," Tenney noted, "persons have assumed to be lawyers, possessing little or none of the acquirements necessary for true professional success." The "injudicious legislation" to which Tenney referred was a Maine statute passed in 1843 , following on the heels of a New Hampshire law of 1842 , that required that applicants to the bar possess, simply, "good moral character," however defined and verified. All educational requirements were dropped, perhaps reflecting Jacksonian-era suspicions of monopolies or self-perpetuating aristocratic elites as well as shifting, modern, competitive notions of the relationship between the state and the professions. Tenney viewed the creation of a law school as a judicious way to address the deficiencies of the bar. Although he believed that "something ought to be attempted for [the bar's] immediate restoration," he considered it "questionable"—due to "a leveling spirit abroad"- "whether it can be allayed by direct opposition so well as by a system of education, which will indirectly diminish its influence." 10

Therefore, coming to his third point, Tenney suggested "a school suited to give a thorough law education, in this State, presenting such inducements to students to avail themselves of its advantages, as to secure their attendance, would be the most direct and effectual means to give the profession a high

${ }^{9}$ John S. Tenney to Leonard Woods Jr., 13 May 1850, Woods Administrative Records (1.2.4).

${ }^{10}$ Tenney to Woods, 13 May $185^{\circ}$. 
character." And, he continued, "[a]s no man can be a good and an accomplished lawyer without an education, which is liberal and widely extended, it is peculiarly proper that a school for the study of the law should be connected with an institution founded for the acquisition and diffusion of knowledge of literature and science generally." In short, "a law school in Maine should be connected with Bowdoin College, instead of any other." 11

Finally, the success of the school depended on the quality and reputation of its faculty. "Learned and accomplished professors and lecturers, and such as are known to be so, are indispensable," Tenney advised. "Without men of this character, the school will hardly be desirable if it could succeed, but I think the experiment must fail. I know of one man only, under present circumstances, who can certainly give it the character at its commencement, which would relieve its friends from great solicitude for its success. I can not doubt that with him at its head as a resident instructor, it would start with a character which would screen it from failure." 12 That person, of course, was Simon Greenleaf.

Even though Greenleaf had left his Maine law practice "to acquire a high and lasting reputation as a legal instructor, and as the author and editor of works upon branches of the law ... he is still recollected here with great interest. . . . [H]ere he obtained his professional eminence. We claim him as one of the sons of Maine." If it could be reported "that the services of Mr. Greenleaf can be secured as a resident professor, and that he will allow his name to be connected with the school as its principal instructor, I do not hesitate to say that it would be expedient to vote at once to establish such a department."13

Writing to President Woods on 14 June, Richard Vose, an Augusta lawyer and member of the Bowdoin board of overseers, reported that he had "lately conversed" with Tenney and that

\footnotetext{
${ }^{11}$ Tenney to Woods, 13 May 1850.

${ }^{12}$ Tenney to Woods, 13 May 1850.

${ }^{13}$ Tenney to Woods, 13 May 1850.
} 
both were eager "to aid in forwarding so desirable an object." A grounding in the profession's principles was, Vose argued, an essential element of a legal education. "I declined receiving a young man into my office, to learn the practice, until he had attended the law school at Cambridge to learn the theory of the profession, and he accordingly went there," Vose explained. "There is a disposition among our young men who have selected the law for a profession, to become thoroughly educated, and it is becoming better and better understood every day, that the noise and bustle of an office, is not the best place to acquire a thorough knowledge of the fundamental principles of a most profound science." 14

Campaigning for Greenleaf as vigorously as Tenney, Vose offered a unique perspective on Greenleaf's tenure at Harvard. "A young lawyer formerly a student in my office, and subsequently under the tuition of Mr. Greenleaf at Cambridge, told me a few days since, that notwithstanding the high reputation of Judge Story ... still, as an instructor and lecturer, and as a profound lawyer, the students regarded Mr. Greenleaf as the life of the school, and had he left, and established a school elsewhere, he did not doubt but that many would have followed him." Would not the graduates of Bowdoin College prefer to attend a law school at their alma mater? And would not others find the more favorable cost of living in Brunswick attractive and, even, choose Bowdoin for their undergraduate education with an expectation of then attending its law school? "In my humble opinion," Vose told Woods, "a law school established any where in New England, under the supervision of Professor Greenleaf could not be regarded in the light of an experiment. His high reputation as a jurist, his great legal attainments, his moral and religious character, so well known and appreciated, that peculiar security of manner, which render him so agreeable to any one, are the peculiar qualifications which must ever render him an acceptable instructor to young men." ${ }^{15}$

\footnotetext{
(1.2.4).

${ }^{14} \mathrm{R}$. H. Vose to Leonard Woods Jr., 14 June 1850 , Woods Administrative Records ${ }^{15}$ Vose to Woods, 14 June 1850.
} 
Greenleaf, however, would have none of it. In June, even though he was then visiting in Brunswick, he wrote a long letter to Woods to memorialize, absolutely and finally, his intentions. "In compliance with your suggestion made to me last week," he declared, evidently reiterating points he had already made to Woods in person, "I proceed to state, in this form, the substance of my remarks to you respecting the proposed Law School in Bowdoin College." He agreed with those who had been polled that establishing a law school in Maine was a worthy endeavor. "Indeed, if thorough education in any science is conducive to the well being of the State, it seems necessary in that of the law, above all others, since it has so intimate a relation to the fabric of our government. Maine has furnished an additional motive for this, by having opened the practice of law, to all persons, even those most ignorant of its principles; thus greatly multiplying the tendencies to an increase of pettifogging, with all its concomitant evils." 16

Again stressing the requirement for a sound financial strategy, he identified the school's two major expenses as its "library \& its instructors, which is the greater I am unable to say; but both are indispensable to its success." Building the library would be a slow, time-consuming, and costly process, with "from five to ten thousand dollars [being] the least that ought to be started with, ... . [and] a sum equal to the income of a capital of five thousand dollars" thereafter being "annually applied to its increase." The funding problem was particularly vexing because, as Greenleaf observed, "I take it for granted that the proposed Law School must be sustained without drawing upon the present funds of the college; \& that its support must therefore be derived either from new funds, obtained for that purpose, or from the tuition fees. Probably from both. It would be necessary therefore that students should be attracted to it in such numbers as to support the

\footnotetext{
${ }^{16}$ Simon Greenleaf to Leonard Woods Jr., 24 June 185o, Woods Administrative Records (1.2.4).
} 
School, with the aid of such permanent funds as might be given." 17

As for pedagogical technique, Greenleaf once again shared his experience at Harvard. "The method of instruction by written lectures, read to the students was tried at Cambridge in the infancy of the Law School, \& afterwards abandoned. While I was there, for a period of fifteen years, not more than half that number of written lectures were read, \& then only on stateoccasions. We relied on oral examinations of the students, upon the text read each day, accompanied with our own expositions, \& upon the moot-court exercises, as the efficient means of instruction. These methods have a freshness \& force which no written lectures can ever possess." ${ }^{18}$ In effect, Greenleaf was describing what would evolve into Christopher Langdell's postCivil War approach to legal education at Harvard, an early, vaguely Socratic version of the case method, without the cases.

Greenleaf once more declined, however, to take a direct role. "For myself the labor \& responsibility of creating, as it were, a new institution of this kind, is more than at my age, \& with reduced energies, it would be prudent for me to undertake." In his stead, Greenleaf recommended that Judge Tenney be appointed the primary instructor. Describing Tenney as "already designated by the public voice"-a curious observation given the attention that appeared to have been focused exclusively on Greenleaf-he concluded, "I know not where to look for a better selection, regard being had to learning, high public estimation, aptness to teach, \& amenity of manners." The aim was to transplant to Bowdoin the dual-professor model of university legal education that Greenleaf and Story had established at Harvard. If Tenney were "induced to transfer his residence to Brunswick, \& give to the Law School such portion of his time as could be spared from his judicial duties" (terms such as Story had secured at Harvard), "it would be a most desirable

\footnotetext{
${ }^{17}$ Greenleaf to Woods, 24 June 1850.

${ }^{18}$ Greenleaf to Woods, 24 June 185 o. For an analysis of the so-called text-andrecitation method, see John H. Langbein, "Law School in a University: Yale's Distinctive Path in the Later Nineteenth Century," in History of the Yale Law School, pp. 53, $54^{-} 5^{6}$.
} 
acquisition." However, "another professor would be required, to devote himself constantly \& exclusively to the charge \& duties of the School, having the library also under his eye" (the role Greenleaf had assumed in Cambridge). ${ }^{19}$

When the Kennebec bar also approached Greenleaf in August with its "sentiment" that he lead the new law school, he pointedly, almost impatiently, quoted from his letter to Woods, again pleading age and diminished energies. ${ }^{20}$ In September, the governing boards of the college met and approved, in principle, the establishment of a professorship of law as long as the position could be adequately funded and financially selfsustaining. And once again, the college drew on Greenleaf's expertise. The governing boards voted that Greenleaf and Tenney should form "a committee to prepare and present, for the consideration of the boards, a plan for the organization of the law department." 21

\section{$\sim$}

Woods was apparently unaware that Greenleaf, in the meantime, had been communicating with another university president about developing a law school. On 1 December 1849 , Francis Wayland, one of the most significant mid-nineteenth century theorists of American educational reform, ${ }^{22}$ wrote to Greenleaf about changes he was proposing to the undergraduate curriculum at Brown University to make it more responsive to what he viewed as America's contemporary needs. Greenleaf knew Wayland, an important figure in Baptist religious circles,

${ }^{19}$ Greenleaf to Woods, 24 June 1850 .

${ }^{20}$ Kennebec Bar to Simon Greenleaf, 8 August 1850, Greenleaf Papers; Simon Greenleaf to J. L. Child, secretary pro tem. of the Kennebec bar, 13 August $185^{\circ}$ (draft), Greenleaf Papers.

${ }^{21}$ Bowdoin College Board of Trustees, Votes and Records (1.1), 4 September 185o, Bowdoin College Archives.

${ }^{22}$ Joseph L. Blau, intro. to Francis Wayland, The Elements of Moral Science (1835; Cambridge: Belknap Press of Harvard University Press, 1963), p. ix: "a central figure in the first great movement for reform of higher education in the United States"; William G. Roelker, "Francis Wayland: A Neglected Pioneer of Higher Education," Proceedings of the American Antiquarian Society, vol. 53 (1944), p. 27: "the best known and probably the foremost educator of his time." 
because the two men shared an interest in evangelical reform and moral science. "[T] eaching in every branch that the various classes of manufacturers, farmers, merchants, teachers \& others would desire" would augment "the present instruction" at Brown and enlarge it "indefinitely," Wayland explained. In addition to soliciting his opinion of the general program, Wayland asked Greenleaf whether he would "be willing, in case it could be carried on, to take a personal interest in it. Should a professorship of Law be established is there any reason to hope that you would again resume your labors as instructor and head of that department[?]"23

Greenleaf responded within the week. On the more general reform proposals, he told Wayland that "I have long thought that what is termed the college course of studies, was not adapted to the wants of the country, at this day, \& that a change like that which you propose was greatly to be desired. I never could discern the reason why a young gentleman, desiring to obtain a complete education as a merchant, a civil engineer, or a practical chemist, should either be shut out from all the advantages which a college might afford, or else be obliged to purchase them at the cost of pursuing other studies of no use to him." The goal, presumably, was to democratize education (although those pursuing a law school at Bowdoin saw it, rather, as correcting a bar admission policy too democratic for their tastes). "Should [Wayland's] college be the first at the North thus to open its doors," Greenleaf predicted, "I doubt not they would be thronged." 24

On the specific matter of the law professorship, Greenleaf declared, "my mind is not quite so clear. . . . There is nothing in my late relations with Harvard, to hinder me from accepting any overture elsewhere- \& my health is now, by the kindness of God so well restored, that I am pursuing my studies \& labors, as heretofore. But I am now engaged in works that will occupy me so closely for nearly a year to come, as to place another

\footnotetext{
${ }^{23}$ Francis Wayland to Simon Greenleaf, 1 December 1849, Greenleaf Papers.

${ }^{24}$ Simon Greenleaf to Francis Wayland, 6 December 1849, Francis Wayland Family Papers, MS-1C-4, Brown University Archives.
} 
employment out of the question-so that if I were obliged now to decide, it would necessarily be in the negative. . . . At present therefore I can only say that the proposal does not strike me unfavorably $-\&$ express the very grateful sense I entertain of your kind regard in making the suggestion." ${ }^{25}$

Greenleaf had already expressed more interest in the professorship at Brown than he would during the entire episode at Bowdoin. After the Brown trustees met later that month, Wayland wrote to Greenleaf to inform him that the "general idea [of founding a law school] met with favor. . . . If it should succeed it will be a great thing for education among us in $\mathrm{N}$. England. Had it been done 100 years or 50 years since no one can estimate the benefits it would have conferred." Wayland had not felt "authorized" to raise Greenleaf's name with the trustees, and he seemed pleased that he would have some additional time to woo Greenleaf. Might the two meet in Boston at Greenleaf's convenience? ${ }^{26}$

Wayland submitted his official report to Brown's corporation in March 1850. He observed that the assumption that Americans would continue to "be satisfied with the teaching of Greek, Latin, and the elements of Mathematics, was plainly impossible. Lands were to be surveyed, roads to be constructed, ships to be built and navigated, soils of every kind, and under every variety of climate, were to be cultivated, manufactures were to be established, which must soon come into competition with those of more advanced nations, and, in a word, all the means which science has provided to aid the progress of civilization, must be employed, if this youthful republic would place itself abreast of the empires of Europe." The plan for the reformed institution included a template for fifteen "courses of instruction," the last of which was denominated the "Science of Law." 7

Wayland's report was a practical, hardheaded, market approach to higher education that, drawing inspiration from his

\footnotetext{
${ }^{25}$ Greenleaf to Wayland, 6 December 1849.

${ }^{26}$ Francis Wayland to Simon Greenleaf, 19 December 1849, Greenleaf Papers.

${ }^{27}$ Report to the Corporation of Brown University, on Changes in the System of Collegiate Education (Providence: George H. Whitney, 185o), pp. 12, 52-53.
} 
two major works, The Elements of Moral Science (1835) and The Elements of Political Economy (1837), also incorporated his insights about acquisitive individualism in a Christian republic. "To Wayland," as educational historian Theodore Crane explains, "ethical principles were part of the system of law by which God ruled the universe, and the study of morals was a 'science,' analogous to natural philosophy, political economy, and systematic rhetoric." ${ }^{28}$ Wayland's challenge, according to historian Mark Schantz, was to reconcile "the tension between the pursuit of worldly wealth and the practice of piety." 9 Though his educational philosophy might be seen as a particularly robust and confident example of an American Whig's faith in progress, it also betrays a darker, evangelical anxiety. Would America lose its moral compass in its embrace of wealth; would capitalism and its excesses of liberty undermine the republic? Law might help mediate the opposition between wealth and piety if it could be trusted to be both scientific and moral; law also might form the basis for instructing the populace about the temptations of the marketplace.

Greenleaf seemed to share Wayland's concerns. Shortly before his death, in 1853 , Greenleaf wrote to his friend Francis Lieber, the legal and political philosopher, that "it is an old truth that Mammon is the god of this world. The lust of wealth \& power is fast driving our own nation forward in a reckless \& wild career of ambition \& folly that I fear will sap our institutions at their foundation. But I emerge from the gloom of anticipated ruin, with the joyful assurance that though

\footnotetext{
${ }^{28}$ Theodore R. Crane, Francis Wayland: Political Economist as Educator (Providence: Brown University Press, 1962), p. 23.

${ }^{29}$ Mark S. Schantz, Piety in Providence: Class Dimensions of Religious Experience in Antebellum Rhode Island (Ithaca: Cornell University Press, 200o), p. 161. Various aspects of Wayland's economic and political thought are examined in Mark Y. Hanley, Beyond a Christian Commonwealth: The Protestant Quarrel with the American Republic, 1830-186o (Chapel Hill: University of North Carolina Press, 1994); Stewart Davenport, Friends of the Unrighteous Mammon: Northern Christians and Market Capitalism, 1815-1860 (Chicago: University of Chicago Press, 2008); Wilson Smith, Professors and Public Ethics: Studies of Northern Moral Philosophers before the Civil War (Ithaca: Cornell University Press, 1956); and D. H. Meyer, The Instructed Conscience: The Shaping of the American National Ethic (Philadelphia: University of Pennsylvania Press, 1972).
} 
demagogues, foreign \& domestic, may harm us for a season, it is God that reigns over all." 30 Thus, teaching law as a moral science to young gentlemen, especially those who universities would not have enrolled in the past because they lacked sufficient status or "character," made a good deal of sense and, in theory, reduced the risks of opening up American higher education to a broader segment of the population. Law, presumably reflecting moral content, would provide safe and secure rules. And for Wayland, no individual was better qualified to supervise such a moral, scientific course in legal studies at Brown than Greenleaf, a fellow evangelical who, by the end of 1851 , had decided to forsake the low-church branch of the Episcopal Church and seems to have been considering joining the Baptist Church. ${ }^{31}$

One more piece of circumstantial evidence points to Greenleaf's relationship to prominent Baptists and helps explain why he may have been drawn to Wayland and the proposed law school at Brown. On 22 July 1850, Daniel Webster resigned from the United States Senate to become secretary of state in the cabinet of President Millard Fillmore. George N. Briggs, the Whig governor of Massachusetts and a devout Baptist, was charged with appointing a successor to Webster. ${ }^{32}$ Lying in the Greenleaf Papers at Harvard is a telegram from Briggs,

\footnotetext{
$3^{\circ}$ Simon Greenleaf to Francis Lieber, 6 May 1853, Francis Lieber Papers (LI 1587), Huntington Library.

${ }^{31}$ See Francis Wayland to Simon Greenleaf, 18 December 1851 , Greenleaf Papers. As late as January 1850 , Greenleaf reported that the Episcopal bishop in Boston, Manton Eastburn, "styles me 'the lowest churchman in his Diocese," and he went on to complain that "the endeavors I have made to obtain either a revision of the Liturgy, or some authoritative declaration of the Church against Puseyism \& incipient Romanism among us, though I have not gone a step beyond our late venerable Bishop Griswold in this matter, have lost me the confidence of all high Churchman, \& these are a majority in this region, at least among the clergy." See Simon Greenleaf to Elliott Cresson, 26 January 1850, Simon Gratz Autograph Collection [025oA], case 6, box 4. Historical Society of Pennsylvania. Greenleaf's frustration with the direction of the Episcopal Church in Massachusetts led him to sever his affiliation. See the letters responding to Greenleaf's resignation: B. P. Aydelott to Greenleaf, 5 July 1851, and John S. Stone to Greenleaf, 1 December 1851, Greenleaf Papers. Greenleaf seemed to be looking for another evangelical home; therefore he contacted Wayland.

${ }^{32}$ On Briggs's faith and its political implications, see Ronald P. Formisano, The Transformation of Political Culture: Massachusetts Parties, 1790s-1840s (New York: Oxford University Press, 1983), p. 300.
} 
addressed to Greenleaf "care Rev. Mr. Croswell," Greenleaf's son-in-law, in Brunswick, Maine, where Greenleaf was apparently visiting. The telegram, dated 27 July 1850 , reads as follows: "(Confidential) Dear Sir: Will you accept the office of U.S. Senator and leave for Washington forthwith? If an answer is not received here by three o'clock P.M., it will be too late." 33 Briggs's intent is not clear. Perhaps he was seeking to quell widespread party conflict by appointing a man without any obvious, long-term political ambitions. Perhaps he considered a fellow member of the evangelical network the safest, most expedient short-term choice for the post. In any case, Greenleaf's response, if there was one, does not seem to have survived. On 27 July (the very date of his telegram to Greenleaf), Briggs named Congressman Robert C. Winthrop to succeed Webster in the Senate. ${ }^{34}$

In mid-September 1850 , just two weeks after being appointed to a committee charged with drafting a plan for the law school at Bowdoin, Greenleaf finally declined Wayland's overture. Although he regretted losing the opportunity to share with Wayland "the good work of impressing on young minds the views we both entertain of the nature \& obligations of Law," and although he found it difficult to forgo "the society, the emolument, \& above all, the opportunity of extensive usefulness," he feared that "the demands of a new \& original enterprize like the one proposed" discouraged him from abandoning "my present pursuits \& connexions, which are alike pleasant

${ }^{33}$ George N. Briggs to Simon Greenleaf, 27 July 1850 (telegram), Greenleaf Papers. ${ }^{34} \mathrm{On}$ the episode, see Michael F. Holt, The Rise and Fall of the Whig Party: Jacksonian Politics and the Onset of the Civil War (New York: Oxford University Press, 1999), pp. 579-83; Kevin Sweeney, "Rum, Romanism, Representation, and Reform: Coalition Politics in Massachusetts, 1847-1853," Civil War History 22 (1976): 116, 119-29; William Gleason Bean, "Party Transformation in Massachusetts with Special Reference to the Antecedents of Republicanism, 1848-1860" (Ph.D. diss., Harvard University, 1922), pp. 39-112; and David Donald, Charles Sumner and the Coming of the Civil War (New York: Knopf, 1960), pp. 183-204. In April 1851, after a prolonged election, Winthrop lost the seat to Charles Sumner (Donald, pp. 200-202). I have not found an account of Briggs's proposition to Greenleaf in any political history of the period. To be sure, had he known about it, Winthrop would not have been inclined to mention it (see his A Memoir of Robert C. Winthrop [Boston: Little, Brown, 1897], pp. 130-34). 
\& profitable, in order to form new relations, among strangers, which at best must be slight \& on the surface." Again, as he had with Woods, he pleaded "advanced age" and "impaired energies." As he reflected on his present position, he recognized that he was "well settled in Massachusetts, in the midst of old \& tried friends, \& connected with several of our most important religious \& benevolent societies." Thus, he thought it "unwise to leave these associations \& remove to another State, even to take so honorable \& useful a position as the one proposed." 35

In the end, Greenleaf concluded his negotiations with Wayland much the same way he had those with Woods. He left open the possibility that he might participate in some occasional, part-time capacity, but a full-fledged, permanent, residential commitment was out of the question. In 1851, the published laws of Brown University, which codified the provisions for implementing Wayland's proposals, announced that a "Law School shall be established as soon as the funds of the Institution shall render it practicable." Each of the courses of instruction listed in the 1850 report was given a full description, except law, and with that omission the proposal for a law school at Brown was quietly abandoned. ${ }^{36}$ Meanwhile, the job of drafting a plan for Bowdoin's law school fell to Greenleaf.

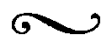

In February 1851, Tenney informed Woods that he would not be able to attend a meeting in Boston about the proposed law school. "I hope you and Prof. Greenleaf will give the subject, committed to him, to you and myself, all the attention, which the importance of the object and the strong desire, which you both feel for its promotion, demands; and I have no doubt, that when we meet I shall concur in any plans, which you may adopt."37 After identifying a prospective donor, Josiah

\footnotetext{
${ }^{35}$ Simon Greenleaf to Francis Wayland, 17 September 185o, Wayland Family Papers, MS-1C-4.

${ }^{36}$ The Laws of Brown University (1851), pp. 5-9.

${ }^{37}$ John S. Tenney to Leonard Woods Jr., 4 February 1851, Woods Administrative Records (1.2.4).
} 
Little of Newburyport, Massachusetts, who eventually endowed a chair in natural science at Bowdoin, ${ }^{38}$ Tenney reiterated his old complaint about the status of the bar in Maine. "The necessity of raising the character of the legal profession, is daily seen. Legislation has been such, that the bond of union among its members is already weakened, if not absolutely broken. Formerly we had a Bar, which was well organized, and it felt that it must be kept pure in moral character, and elevated in legal and general learning. But since any man, who desires it can practice in our highest courts, without any professional study at all, and no other evidence of good character, than certificates from some individuals who may not be known [to] the Court, the Bar has little to do, as they had when no one could become a member, excepting through its recommendation." Some renewed gate keeping was necessary to protect the integrity of the bar. "The wish that there should be a law school in connection with the College is very general among lawyers," Tenney concluded, "but many entertain doubts, whether the requisite means can be obtained. But energy and perseverance has done $\&$ can still do greater works, without the pecuniary means at the outset, and even in opposition to the united popular will."39

In May, Tenney was back in touch with Woods, responding to his inquiries. He reassured Woods that he had correctly read the college charter as permitting the creation of a law school. And he addressed Woods's question "What is the most appropriate mode to lay the basis of a law school?" much as Greenleaf had done the previous year by focusing first on the library. "A law school without a library would be an anomaly," Tenney insisted. "The law in this respect is very different from the branches taught to the undergraduates, who are expected to furnish their own text books, they being few in number and inconsiderable in value." He went on to elaborate his point:

It is true the leading principles and maxims of the law may be found in a few elementary treatises. But the cases reported when they are

\footnotetext{
${ }^{38}$ The Josiah Little Professorship in Natural Science was established in ${ }^{1864}$. See Hatch, History of Bowdoin, p. 107.

39Tenney to Woods, 4 February 1851.
} 
practically applied are infinitely varied, and nice distinctions are pointed out on which the results may have depended. Important principles are here expanded and inferred by great general learning and the power of argument, which cannot fail to make lasting impressions upon the mind of one engaged in the study. And it is by an acquaintance with the progress which the science has made, that we see the vast fabric, which has been centuries in building, and perceive the beauty of the proportions, which modern legislation has not been successful in essentially marring. In a library alone, can a lawyer feel his duties and responsibilities, and be induced to labor as he should do, to acquire any professional distinction..$^{40}$

Law, then, was a science, and the library provided some semblance of order in the increasingly complicated task of ascertaining and mastering the complexities of law's evolutionary character and its nuanced meanings.

Ever cautious, Tenney recommended that once Bowdoin had "obtained" a law library, it could embark on a modest experiment. Establishing a law school was a risky venture, he worried, and "failure would be deeply mortifying." He urged, instead, that "a course of lectures embracing only a few subjects might be delivered to the senior class in college and such others as might choose to attend upon the payment of a moderate fee. . . . [I]f the experiment should be followed by general favor \& patronage, a course of instruction might" ensue. Like Greenleaf, Tenney took Harvard as his model. "The lectures of Judge Parker under the Royal $[$ sic] fund exerted attention to the subject. Mr. Dane was interested, and the school under Judge Story \& Professor Greenleaf attained the growth, which gave all lawyers in New England pleasure to see."41 Greenleaf's withdrawal as a candidate for the school's first full-time professor had evidently roused Tenney's misgivings. That summer he received Greenleaf's draft report, apparently intended for the governing boards' scheduled meetings at September commencement.

\footnotetext{
$4^{\circ}$ John S. Tenney to Leonard Woods Jr., 27 May 1851, Woods Administrative Records (1.2.4).

${ }^{41}$ Tenney to Woods, 27 May 1851. Parker had been the first Royall Professor.
} 


\section{O}

Greenleaf's report was not a detailed plan. It did not, for instance, lay out a course of study as had Harvard Law School's published catalogues during the 1840 os and early 185 os. $^{4^{2}}$ Rather, the document was more in the character of a jeremiad, or at least an admonition, an expression of acute cultural anxiety about the fate of a republic that was facing multiple threats. A law school could serve as a bastion against such impending doom. The dangers Greenleaf identified ranged from the declining status of the bar (as voiced repeatedly by Tenney) and the scourge of immigration to concerns stated less directly about resistance to the Fugitive Slave Law and its impact on the rule of law. The report looked backward for inspiration to Greenleaf's 1834 inaugural lecture as Royall Professor of Law at Harvard and forward to the challenges of maintaining order in a society increasingly buffeted by public opinion and robust expressions of democratic sentiment capable of inciting faction and disharmony. Lawyers must be trained to repel the excesses of those sentiments in order to remind and guide the public about the moral virtues of a civil society devoted to divinely inspired law.

Reflecting on the law's role in a republic, Greenleaf reminded his readers of "a familiar truth, that our government is a government of law, that law is the will of the sovereign, . . \& \& that, with us, this sovereign is the people." But embedded within that truth lurked a fundamental problem: the trustworthiness of the people. "So strong \& prevalent is this principle of our institutions, that its excessive action is often painfully felt, \& it is found that the will or rather the passion of the people, however irregularly expressed, whether in the public prints, or in the uproar of popular tumult, has a force sufficient to influence the conduct of public offices, \& sometimes even to affect the interpretation or impede the execution of the plainest laws. This is an evil [as, Greenleaf noted, even Washington had lamented in his Farewell Address] inherent in the nature of all

\footnotetext{
$4^{42}$ See A Catalogue of the Students of Law in Harvard University (1845), pp. 8-10,
} and A Catalogue of the Students of Law in Harvard University (1851), pp. 11-13. 
free institutions." A law school, offering a sustained emphasis on the root "obligation to obey every requirement of law, in its broadest sense," would serve as an essential guide for a nation whose course required periodic correction. ${ }^{43}$

Public opinion, especially its influence on the legislative and the judicial processes, had long occupied Greenleaf's mind. Briefly mentioning the problem in his 1834 Harvard inaugural lecture, he viewed it then as a civilizing force in opposition to the expression of "brute force," particularly when "the power of public opinion, [was] regularly expressed through the medium of law." In 1837, writing to Lieber, Greenleaf clarified his attitudes about popular sovereignty. "This invisible but resistless power is also called public opinion," he explained. "By this is meant not the blind will of the populace; but the consenting suffrages of reflecting minds, including both unlearned and learned." 44 The following year, Greenleaf took up the issue of popular sovereignty specifically as it related to the legal profession in his introductory lecture "at the present term" of the Harvard Law School. "The great business of the lawyer," he wrote, "is to ascertain this public will . . . as it is heard in the harmonious system of a liberal science, permanent in its principles, essential to the well being of his country, and concerning itself with the happiness of its race. It is the united wisdom of men, seeking the good of each other. Our profession, therefore, is not to be regarded as a mere trade, or an instrument of

43"Committee Report on the Establishment of a Law Department," 3 September 1851, Woods Administrative Records [1.2.4.1, box 1, folder 57]. The report is not paginated. A draft of the report is in the Greenleaf Papers, Harvard Law School Library, http://nrs.harvard.edu/urn-3:HLS.Libr:9527402. The final report, which is held in the Bowdoin Archives, incorporates Greenleaf's editorial and stylistic changes to the draft; there do not appear to be any substantive differences between the draft and the final versions. Unless otherwise noted, I am quoting from the final report throughout this section of my essay. Greenleaf had referred to Washington's warnings about the dangers of "public opinion" in his inaugural lecture at Harvard (Simon Greenleaf, A Discourse Pronounced at the Inauguration of the Author as Royall Professor of Law in Harvard University, August 26, 1834 [Cambridge: James Munroe and Company, 1834], p. 23).

${ }^{44}$ Greenleaf, Discourse Pronounced at the Inauguration, p. 7, and Simon Greenleaf to Francis Lieber, 26 October 1837, Lieber Papers (LI 1568). The letter is reprinted in its entirety in M. H. Hoeflich and Ronald D. Rotunda, "Simon Greenleaf on Desuetude and Judge-Made Law: An Unpublished Letter to Francis Lieber," Constitutional Commentary 10 (1993): 93, 98 . 
political advancement; but as an honorable department of public labor, involving duties of the utmost moment to the men, both of our own and future times." 45

By the time he prepared his report for Bowdoin, Greenleaf had apparently become less sanguine that public opinion was an expression of a "united wisdom," and he sought his justification for an obedience to the law elsewhere. He found that the obligation originated in God and in faith. Woods and the orthodox Bowdoin faculty would have immediately understood the epistemology and the evangelical message. "Our youth should early be taught, that the obligation or binding force of law has an origin higher than any human enactment or penal sanction," Greenleaf now argued, "it being found in the will of Him who is the God of Order. . . . It is He who instituted government, from its seminal form in the family, to its broader development in tribes \& nations; inculcating every where the duty of obedience to the sovereign will, whether patriarchal or popular, whether the paramount will of the entire community, or whether it be the will of only some legally corporate portion, constituted for educational, commercial, charitable or religious purposes. . . . It should, therefore, be impressed on the minds of our youth," he went on, "that all laws \& regulations, adopted as rules of human conduct, \& not plainly \& directly contrary to the revealed will of God, are binding on the consciences of all men, until they are either repealed, or adjudged void by the legal tribunals." 46

As he had done in his inaugural lecture at Harvard, Greenleaf grounded his appeal in the language of Richard Hooker, the influential Anglican theologian of the late sixteenth century: "'Of law there can be no less acknowledged, than that her seat is the bosom of God, her voice the harmony of the world." "47 It was a phrase, Elizabeth Mensch has observed, that

\footnotetext{
${ }^{45}$ Simon Greenleaf, "Notes of Professor Greenleaf's Introductory Lecture, at the Present Term," Law Reporter 1 (1838): 217, 218.

46 "Report on the Establishment of a Law Department."

${ }^{47}$ Greenleaf, Discourse Pronounced at the Inauguration, p. 11. For the quotation from Hooker, see Of the Laws of Ecclesiastical Policy, First Book (1593; London: John W. Parker, 1851), p. 99.
} 
early nineteenth-century lawyers were fond of quoting, for it "expressed the assumptions of a hierarchical, epistemological and legal (as well as social and political) model: law contained a substantive truth which descended from God and infused an ordered moral/social structure." ${ }^{8} 8$ In referring to Hooker, Greenleaf was employing a kind of shorthand for what Howard Schweber has termed "Protestant Baconianism" among antebellum legal educators and legal scientists, that is, their emphasis on natural theology and induction. ${ }^{49}$ In 1834 , Greenleaf had declaimed, "Christianity founds it claims to our belief upon the weight of the evidence by which it is supported. The evidence is not peculiar to the department of theology; its rules are precisely those by which the law scans the conduct and language of men on all other subjects, even in their daily transactions." ${ }^{\circ}$ The important inductive lesson, as Schweber notes, was "to find universal natural and governing principles for human affairs." 1

Maine's "unfortunate act of legislation" had, however, reduced the practice of law to little more than "a trade to get money by, without any just appreciation of the responsibilities of a lawyer for the peace of his own community, or of the sacredness of his office as a minister in the temple of justice." In his report, Greenleaf drew attention to a number of adverse

\footnotetext{
${ }^{48}$ Elizabeth Mensch, "Religion, Revival, and the Ruling Class: A Critical History of Trinity Church," Buffalo Law Review 36 (1987): 427, 495. Robert Gordon likewise has linked the Hooker passage to the notion in the first half of the nineteenth century that "[1]awyers had, as they saw it, a direct line to God's mind through their knowledge of the principles of legal science, which at their most abstract harmonized with the principles of morals and natural justice, as well as with tradition-derived principles of the common law" ("The Path of the Lawyer," Harvard Law Review 110 [1997]: 1013).

${ }^{49}$ Howard Schweber, "The 'Science' of Legal Science: The Model of the Natural Sciences in Nineteenth-Century American Legal Education," Law and History Review 17 (1999): 421, 423. According to Schweber, the method "had four outstanding characteristics: a commitment to natural theology, the doctrine that the study of nature proved religious truths; a commitment to a limited form of inductivism that defined science as fundamentally an exercise in taxonomy; a belief in a grand synthesis of analogies; and the claim that science was a public undertaking that would produce moral and political uplift" (p. 423).

$5^{\circ}$ Greenleaf, Discourse Pronounced at the Inauguration, p. 23.

${ }^{51}$ Schweber, "Natural Sciences in Nineteenth-Century American Legal Education," p. $45^{\circ}$, discussed more generally at pp. $44^{6-52}$.
} 
effects that the legislature's ill-conceived measure had caused. With the legal profession now open to more less-qualified practitioners, litigation had become rampant, a "virus" that would "spread among the people," who would also be more likely to fall prey to charlatans. Respect for the law would "be correspondingly diminished," as it was used increasingly as a "snare for the unwary." "Such a state of things," he observed, "has always been found to exist, in the immediate neighborhood of every ignorant \& unprincipled lawyer; \& this state will continue $\&$ increase, in proportion as the number of such scourges shall be multiplied." A law school in the state would, he predicted, "exert a salutary counteracting influence," for by increasing the number of "ingenious young men" who sought to improve themselves by means of a prestigious legal education, "the unworthy can be excluded," and thus "the tone of professional morals" in the state would be elevated. A local law school, in other words, might stem the exodus from Maine of highly qualified aspiring lawyers, who had little option for obtaining a university legal education save at Cambridge.

In an era of unregulated standards of admission to the bar, the law school offered a significant advance over legal apprenticeship, and certainly over no training whatsoever, insofar as it provided the opportunity for law school faculties to teach, in an organized fashion, the ethical principles being articulated by the country's leading practitioners. It is probably no accident that the impulse to codify early rules of professional responsibility coincided with the drive to expand entry into the profession beyond traditional elites, whose character was presumably above reproach. If you could no longer vouch for character in every instance, perhaps you could inculcate the ethical formulas, methods, and insights of the past. In Greenleaf's view, the lawyer's role in society was an expansive one. Although an attorney owed obligations to his client, his "first duties," Greenleaf asserted in his 1834 Harvard inaugural discourse, "are to the community in which he lives, and whose peace he is bound to preserve." A lawyer was to be "a peacemaker; - a composer of dissensions; - a blessing to his neighbors. . . . I look with pity on the man," he wrote, "who regards himself a mere machine 
of the law; - whose conceptions of moral and social duty are all absorbed in the sense of supposed obligation to his client, and this of so low a nature as to render him a very tool and slave, to serve the worst passions of men;--who yields himself a passive instrument of legal inflictions, to be moved at the pleasure of every hirer; - and who, beholding the ruin and havoc made by a lawsuit . . . can calmly pocket his fee with the reflection, that he had done his duty to his client, alike regardless of duty to his neighbor and his God." 52 In other words, the lawyer should be motivated by a responsibility to prevent or mediate conflicts rather than a desire to profit from them. He should be responding to a higher calling than simply his own or his clients' selfish interests.

Greenleaf had expressed his attitudes about the fundamental obligations of legal representation even before his address at Harvard. Beginning in the 1820 s, while still practicing law in Maine, he had prepared a number of pieces for the American Tract Society. In "To a Person Engaged in a Lawsuit," of which the Tract Society printed 48,ooo copies, Greenleaf asked, "Did you try every other mode of reconciliation and redress in your power before you committed your cause to the decision of the law? . . . Or have you availed yourself of the mediation of friends, or neighbours to effect a peaceable and friendly settlement? . . . Do not say that it is his business to come to you; for this is not the temper that will bring you together." "I pray you," implored Greenleaf, "whether, before you appealed to the law, you honestly endeavoured, in the spirit of Christian kindness and liberality, to become reconciled to your adversary; or to persuade him, by mild though earnest expostulations, to regard your rights?" Were you following a path "of love, and kindness, and charity, and mercy," he inquired, or of "anger, and revenge, and a severe and unforgiving temper?"53 The message was staunchly evangelical, supported by quotations from the gospels and references to Christ's sacrifice

$5^{2}$ Greenleaf, Discourse Pronounced at the Inauguration, pp. 16-17.

${ }^{53}$ Simon Greenleaf, "To a Person Engaged in a Lawsuit," Publications of the American Tract Society, vol. 6, no. 168 (New York, [1829-30?]), pp. 94-95, 98, 99. For the 
for all humanity, and although in this instance Greenleaf was addressing it to litigants, he used remarkably similar language to construct an image of the "good lawyer."

In his Bowdoin report, Greenleaf detailed the proper character and conduct of this "good lawyer."

The lawyer who has a just view of his position \& duty will never commence a suit where the dispute can be amicably settled, nor until all available means of friendly adjustment are exhausted;- - he will never enter a cause in Court, that can by reasonable efforts be kept out, nor suffer one to remain pending, if the parties are in a situation to be brought together for negotiation;- - he will never mislead the Judge, nor disguise facts from the jury;- -he will not permit himself to be used as an instrument to gratify the passions of a bad man; nor be guilty of polluting the conscience of his client, or of weakening the reverence of any man for the oath of God. On the contrary, he will feel \& act as a peacemaker; as charged with a large amount of responsibility for the preservation of public tranquility \& the promotion of good morals; he will exert himself to strengthen the bonds of society, - to uphold the institutions of education \& of religion; realizing the truth, that to be a good lawyer, he must be a good man. Now this is the character which, in the Law Schools of New England, it is the aim of the instructors to impress on their pupils; \& the endeavor has evidently been attended with encouraging success. And while these seminaries are productive of such results, the existence of a Law School will be deemed essential to the well-being of every State; as much so as any of the higher Schools of learning. ${ }^{54}$

As the era progressed, Greenleafs "good lawyer" may well have found himself a member of an increasingly distinct minority. By the close of the century, client-driven zealous advocacy and role-differentiated morality dominated legal practice. The morally activist lawyer, committed to the ideals of civic republicanism and devoted to disinterested, public-spirited outcomes

number of copies printed, see William A. Hallock Jr. to Simon Greenleaf, 22 February 1832, Greenleaf Papers.

${ }^{54}$ In an 1846 Harvard lecture, under the heading "True character \& idea of the Law School," Greenleaf had proposed "its object-to make good lawyers out of good men" ("Address at close of Spring term 1846," Greenleaf Papers; see also, M. H. Hoeflich, "Roman Law in American Legal Culture," Tulane Law Review 66 [1992]: 1723, 1729). 
to serve the good of the community at large, became a figure of the past, if that view of lawyering was ever as extensive as Greenleaf imagined. 55 What Greenleaf's defense of a relatively other-directed set of norms suggests is that they derived not simply from the ideals of republicanism and civic virtue but also from the core values of Christian evangelicalism as well. The forces of capitalism, with interests arrayed against each other in the marketplace, may have contributed to an accelerated reliance on zealous advocacy. Greenleaf after all had noticed the tension between God and Mammon.

Contributing to this rising spirit of contention was the plague of uneducated, immoral lawyers that had been unleashed on an unwitting public. Such poorly trained practitioners were not capable of being effective agents of social control or, as Joseph Story phrased it, "public sentinel[s]." ${ }^{6}$ The need to guard against the excesses of the people was especially pressing, Greenleaf believed, in a period of massive immigration. The year before he submitted his report to Woods, Greenleaf wrote a long letter to C. J. A. Mittermaier, who taught at Heidelberg, in which he discussed the Boston trial and execution of Dr. John Webster for murdering Dr. George Parkman. Reflecting upon the case's relationship to debates about capital punishment, he observed, "I am inclined to think that, in this country, it is not generally thought safe to abolish the punishment of death for the crime of murder, especially as the crime has become more frequent in the last two or three years, from the great increase of foreigners, of the lowest class among us, exported from the prisons, lazarettos \& poor-houses of Europe, \& especially those of England \& Ireland. The revolutions in Europe, also, drive to our shores very many of the most reckless \& restless spirits of the old world; \& none of

55 For a skeptical view of the centrality of morally activist lawyering and a claim of the widespread acceptance of zealous advocacy before the Civil War, see Norman Spaulding, "The Myth of Civic Republicanism: Interrogating the Ideology of Antebellum Legal Ethics," Fordham Law Review 71 (2003): 1397.

${ }^{5}$ Joseph Story, Discourse Pronounced Upon the Inauguration of the Author as Dane Professor of Law in Harvard University, on the Twenty-Fifth Day of August, 1829 (Boston: Hilliard, Gray, Little, and Wilkins, 1829), p. 25. 
these classes are sufficiently enlightened, or imbued with moral principle, to appreciate the blessings of true liberty." 57

With more than a touch of nativism and Know-Nothingism, Greenleaf returned to the problem of immigration in his Bowdoin report, where he considered as well the proposed law school's likely role in addressing it.

The vast extent of our western territory, it is well known, has received a tide of immigration, without example in modern history. In this mass there is a large proportion of ignorant men, starved out of Europe, \& of the restless \& active spirit of the old world, men without religion or moral principle, foes of all manner of legal restraint, mistaking licentiousness for liberty, \& having no just conception of the nature of free government. In that wide country, thus peopled, the greater part of the professional men, \& especially the lawyers, are sons of New England. Nothing is more common, than for a student of law, on his admission to the bar here, or previous to it, to seek his fortune in the West. The legal doctrines \& the professional morals which he may carry with him are therefore matters of great moment, because of the controlling part he may take in founding, administering, or giving character to the institutions \& laws of that portion of our country; \& these principles \& this moral code must receive their form $\&$ impress in the colleges \& Law Schools of the East.

In such turbulent conditions, Greenleaf declared, the student must be "warned against mistaking the impulses of blind passion, or of unenlightened conscience, or of morbid sentiment, for the voice of some higher law, or divine command. He should be taught, that in a country, furnished with learned, upright \& independent tribunals, authorized to decide upon the obligatory character of every law, their decision, in every case of doubt, furnishes the true rule of conduct \& measure of duty, by the law of God as well as of man; \& that to invoke the aid of any other rule or guide in such cases, is warranted by

\footnotetext{
${ }^{57}$ Simon Greenleaf to C. J. A. Mittermaier, 24 October 185o, C. J. A. Mittermaier Papers, Heidelberg University Library, Heid. Hs. 3718, 17 G 4. For accounts of the famous so-called Harvard murder trial, see Robert Sullivan, The Disappearance of Dr. Parkman (Boston: Little, Brown, 1971), and Simon Schama, Dead Certainties (Unwarranted Speculations) (New York: Knopf, 1991).
} 
no principle, human or divine." The system being thus established, Greenleaf emphasized, the "first duty of a good citizen" is "obedience to law."

Given the social conditions of his time, it is understandable that Greenleaf linked obedience to the law with immigration, but he may have had another matter in mind as well. As part of the Compromise of $185^{\circ}$, a new fugitive slave law had been enacted. By 1851 , the law was being regularly resisted in Boston, in some instances by force. Early that year, the fugitive slave cases of Frederick "Shadrach" Minkins and Thomas Sims drew widespread public attention, prompting debate and uproar. Near the end of April, the month of Sims's arrest and rendition, Greenleaf wrote to Lieber that " $t$ the North is going right on the subject of law \& order, though the fugitive slave law, in not providing for a trial by jury, \& in an insulting distinction in the commissioners' fee, between cases decided for \& against the claimant, is deservedly odious to us all, \& has greatly embarrassed \& hindered the execution of the law." $5^{8}$ Abolitionists might appeal to higher law to justify their resistance, but for all his understanding of the $185^{\circ}$ law's imperfections, Greenleaf seemed to be saying, indeed warning, that the correct view "of higher law, or divine command," required obligation and obedience to all laws. Otherwise, a society was inviting chaos and disorder, for when it defied the law, it repudiated its fundamental truth, as Hooker had articulated it, "that her seat is the bosom of God, her voice the harmony of the world."

In his report to Bowdoin, Greenleaf continued to stress the practical realities of building a library collection, a laboratory of sorts for the study of and research into the law, and he proposed certain undergraduate and law school courses, including common law subjects. But at its core, the law school he envisioned

\footnotetext{
${ }^{5}$ Simon Greenleaf to Francis Lieber, 26 April 1851, Lieber Papers (LI 1585). On the Fugitive Slave Law and resistance in Boston, see Steven Lubet, Fugitive Justice: Runaways, Rescuers, and Slavery on Trial (Cambridge: Belknap Press of Harvard University Press, 2010), pp. 132-56; Albert J. von Frank, The Trials of Anthony Burns: Freedom and Slavery in Emerson's Boston (Cambridge: Harvard University Press, 1998), pp. 26-30; and Leonard W. Levy, "Sims' Case: The Fugitive Slave Law in Boston in 1851," Journal of Negro History 35 (1950): 39.
} 
was not to focus solely on the rational and progressive development of the common law as embedded in historical experience; it was also to find its inspiration within and demonstrate its commitment to faith. Greenleaf had been a prominent and contributing member of and an officer in many of the voluntary and charitable activities of the so-called "benevolent empire" of early nineteenth-century evangelical Protestantism. ${ }^{59}$ He belonged, at one time or another, as fitting a low-church Episcopalian, to both interdenominational and intradenominational tract, Bible, Sunday School, colonization, missionary, temperance, and peace societies and movements. From the evidence in his report to a sympathetic Bowdoin administration, he seems to have concluded that he ought to add law schools to the list of evangelical endeavors in antebellum America.

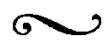

Tenney enthusiastically ratified Greenleaf's report. "I should be sorry to see anything contained in the Report stricken out," he wrote Greenleaf, "especially at this time, when there is so much danger from legislation by the ignorant and inexperienced. Every lawyer, who wishes to preserve the old landmarks, and retain the principles, which have been tested for ages as being conducive to the public good and individual security, owes a duty to the State, in making exertions to prevent innovations which really threaten to change gradually, tho' essentially our dearest institutions. These changes are rather the result of ignorance in the people than any inclination to do what is really against the true interests of the public." ${ }^{\circ}$

Several weeks later, shortly before attending the Bowdoin commencement and the meetings of its governing boards, Tenney informed Woods that he had received, read, and heartily approved Greenleaf's draft report. "The reasons contained

${ }^{59}$ On the "benevolent empire," see Clifford S. Griffin, Their Brothers' Keepers: Moral Stewardship in the United States, 1800-1865 (New Brunswick, N.J.: Rutgers University Press, 1960), and Charles I. Foster, An Errand of Mercy: The Evangelical United Front, 1790-1837 (Chapel Hill: University of North Carolina Press, 1960).

${ }^{60}$ John S. Tenney to Simon Greenleaf, 7 August 1851 , Greenleaf Papers. 
therein, for the establishment of such a department in the College are conclusive," he declared, "and must commend themselves to the mind of every man of enlarged views \& who wishes well to the real and permanent good of the State." As to executing the plan, however, Tenney was more circumspect. Money had not been forthcoming. But "[i]f the prospect should be thought discouraging, touching its success, the good results from its establishment, may be anticipated to be so large, that exertions should not be spared, even if the chances should appear more adverse than otherwise. Every year satisfies me, that something of the kind is necessary as remedial, if we have no higher purpose." ${ }^{61}$ On the eve of its submission, then, even the most enthusiastic proponents of Greenleaf's report were conceding that its successful implementation did not appear promising.

The designated Bowdoin visiting committee received "the able and interesting Report of the Committee to whom this subject was referred, and with whose views they concur. It would be a work of supererogation to attempt to add to them." Adopting Tenney's guarded view of the experiment, however, they recommended "that a Professor of Law be appointed, whose duty it shall be to deliver a course of Law Lectures, to the Senior Class annually, until the further order of the Boards, with an annual salary of __.." In a subtle, or perhaps not so subtle, sign of its lack of commitment to the plan, the visiting committee left the recommended salary line blank. Extending its philosophical support, though, it approved Greenleaf's draft statutes for governing the law school (as attached to his report) as well as his longstanding recommendation that duplicate copies of official government documents be obtained by means of a legislative resolve. They also encouraged the president and the professor of law to gather books and funds as best they could. ${ }^{62}$

\footnotetext{
${ }^{61}$ John S. Tenney to Leonard Woods Jr., 28 August 1851, Woods Administrative Records (1.2.4).

${ }^{62}$ The report is found in Reports of the Visiting Committees, 1851 , Bowdoin College Archives.
} 
The trustees and the overseers responded promptly, voting that a law professor be appointed, that the professor of law be "requested by the President to deliver a course of Lectures to the Senior Class, when he can be sufficiently compensated for the same without a charge upon the present funds of the College," that application be made to the legislature to "procure" a formal resolve on the subject of duplicate government documents, and, finally, as the outcome of all this planning, that "[b]y ballot . . . John S. Tenney be Professor of Law in Bowdoin College." ${ }^{33}$ Although he continued to lecture on medical jurisprudence to students in the medical school, Tenney apparently never discharged any of the responsibilities of Bowdoin's professor of law, perhaps because money sufficient to carry the proposal into effect was never raised. ${ }^{64}$ Interest in the law school waned, but Leonard Woods, undaunted, waited for a decade, until the eve of the Civil War, to reintroduce his plan for a law school at Bowdoin.

\section{$\sim$}

In 1859 John Appleton, a Bowdoin graduate and a member of Maine's Supreme Judicial Court (and Tenney's successor in 1862 as chief justice), wrote to Woods to report on his efforts to raise money to endow the law professorship at Bowdoin. ${ }^{65}$ But it was not until several weeks after the first shots were fired on Fort Sumter that an effort began once again in earnest to revive interest in a law school. On this occasion Woods focused quickly on a candidate as he solicited numerous letters of reference about Isaac Redfield, a prominent legal treatise writer, expert on the law of railroads, and until recently chief

\footnotetext{
${ }^{6}$ See Board of Trustees, Votes and Records (1.1), 3 September 1851, Bowdoin College Archives.

${ }^{64}$ Bowdoin had established a medical school in 1820 ; it closed in 1921. See Hatch, History of Bowdoin, pp. 461-76.

${ }^{6}$ John Appleton to Leonard Woods Jr., 29 March 1859, Woods Administrative Records (1.2.4). On Appleton's career, see David M. Gold, The Shaping of NineteenthCentury Law: John Appleton and Responsible Individualism (New York: Greenwood Press, 1990).
} 
justice of the Vermont Supreme Court. ${ }^{66}$ Redfield, unlike the prospective candidates in the prior decade, expressed interest in the position. ${ }^{67}$ The beginning of a war would not normally strike the casual observer as the most propitious time to undertake ambitious or large-scale projects at small colleges, and, as in the past, the practical problems of acquiring money and books were formidable.

Woods had a novel idea for addressing the library problem, and it involved Greenleaf's estate. Greenleaf had died in 1853. In 1861, Woods wrote to Greenleaf's son-in-law, Andrew Croswell, a minister who had been living in Brunswick when the original law school proposal had been developed but who had been residing in Cambridge since 186o. Woods asked Croswell to make inquiries of James Greenleaf (Simon Greenleaf's youngest son, who also was then living in Cambridge) to ascertain if his father's library might be available for Bowdoin's use to help it reinvigorate Greenleaf's law school plan. Apparently hoping to convince the family of the favored place the idea once had in Greenleaf's heart and mind, Woods sent along Greenleaf's old letters on the subject.

James Greenleaf, a former New Orleans cotton merchant, was not persuaded. Croswell reported "that while Mr. Greenleaf expresses a warm interest in the establishment of the Law School at Brunswick, and especially in the promotion of the plans suggested by his father, yet he feels compelled to decline the proposal made in your letter, for the removal \& loan of the Law Library to the College. It is at present in safe and good keeping in his own house, and the whole movement with reference to the establishment of the Law School seems to him to be involved in too much uncertainty to warrant the change

\footnotetext{
${ }^{66}$ On Redfield's career, see David M. Gold, "Redfield, Railroads, and the Roots of 'Laissez-Faire' Constitutionalism," American Journal of Legal History 27 (1983): 254. For letters of evaluation about Redfield in response to Woods's inquiries, see George C. Shattuck to Leonard Woods Jr., 20 April 1861, and John Appleton to Leonard Woods Jr., 16 May 1861, Woods Administrative Records (1.2.4).

${ }^{67}$ See Isaac Redfield to Leonard Woods Jr., 21 May and 8 June 1861, Woods Administrative Records (1.2.4).
} 
proposed."68 With "[p]ublic affairs being in such a bad condition, and the prospects of the future so threatening, he can hardly believe that the necessary means can be obtained for the adequate endowment of the institution," James Greenleaf's brother-in-law noted. And in a pointed jibe at Bowdoin, James made it known through his intermediary that "he is the more impressed with this conviction from the fact that no action has been taken by the friends of the College, upon the suggestions of his father's letters, during the long and prosperous interval of ten years." Croswell concluded that James "does not wish to sell the library. Should he dispose of it at all, it would be as a donation; but under present circumstances, he prefers to retain it under his control, for ulterior purposes, and such as the future may determine."69 Without further delay, Croswell returned his father-in-law's letters to Woods.

That same month, June 1861, Redfield wrote to Woods that he was "glad that you find so much encouragement in these times. I begin to feel considerable courage about it." Redfield's wife, too, he conveyed, "seems to feel a good deal of courage about the Law School at Bowdoin." $7^{\circ}$ Meanwhile, after what had been a considerable silence, Tenney chimed in. "I have embraced every proper opportunity," he informed Woods, "of introducing the subject of the 'law school'; and find all to whom I have spoken on the subject, have an ardent wish that it may be started, and be successful-but all agree that a pecuniary

\footnotetext{
${ }^{68}$ Andrew Croswell to Leonard Woods Jr., 10 June 1861, Woods Administrative Records (1.2.4). Woods's letter to Croswell has not survived, but its date (27 May 1861) and contents may be gleaned from Croswell's response.

${ }^{69}$ Croswell to Leonard Woods, 10 June 1861 . The library was in fact donated shortly thereafter but almost certainly not under the circumstances James had anticipated or intended. He died "suddenly" in 1865 at age fifty-one (Greenleaf, Genealogy of the Greenleaf Family, p. 144). On 4 July 1866, in the great fire that had consumed the city, the Cumberland Bar Association of Portland, Maine, lost its holdings. Soon after, James's widow, Mary Longfellow Greenleaf (sister of Henry Wadsworth Longfellow), hearing of the loss, donated her father-in-law's library of 1,269 volumes. As the Greenleaf genealogy reported, other volumes had been purchased, "so that the Greenleaf Law Library of the Cumberland Bar is now one of the finest and most useful in the State" (p. 498). For the later history of the library, see the website of the Cleaves Law Library in Portland, Maine.

${ }^{70}$ Isaac Redfield to Leonard Woods Jr., 27 June 1861, Woods Administrative Records (1.2.4).
} 
foundation is essential to its stability and prosperity. I do not find that my associates in office give encouragement that they can do much, by direct donation, but all feel disposed to do what they can, in soliciting subscriptions, and giving aid in other respects." The alumni and others, surely, would be able to raise $\$ 25$,ooo. Tenney was optimistic, too, that Redfield's "reputation as a judge and as a writer on subjects connected with the profession of the law" would at least give "the school a start," if not guarantee that it would flourish. ${ }^{11}$

Tenney, about to step down as chief justice, along with George Evans, an 1815 graduate and a trustee (as well as a former United States congressman and senator), were apparently placed in charge of raising the $\$ 25$,ooo fund..$^{72}$ The task of drafting the subscription paper fell to Evans, though there were a number of strategic questions to sort out, including the legal conditions of the pledges, who should lead off the drive and in what amount, and whether Redfield should be named (apparently he did not wish to be so). The document, dated 20 July 1861 , was a careful statement, designed to protect those making pledges against exposure should the project not come to fruition. At the bottom of the document, only two subscribers were listed: John Tenney, for the amount of $\$ 1,000$, and Nathan Clifford, former Maine lawyer and politician and at that time an associate justice of the United States Supreme Court, for the amount of $\$ 500 .{ }^{73}$ Within the week, Evans reported to Woods that he was having trouble raising money. One alumnus and a college trustee, Ether Shepley, former United States senator, an associate justice, and later chief justice of the Maine Supreme Judicial Court, was described by Evans as "quite prompt \& decided, \& I fear we can expect nothing there. What shall be done?"74

\footnotetext{
${ }^{71}$ John S.Tenney to Leonard Woods Jr., 9 July 1861, Woods Administrative Records (1.2.4).

${ }^{72}$ See the two letters (both of the same date), George Evans to Leonard Woods Jr., 16 July 1861, Woods Administrative Records (1.2.4).

${ }^{73}$ Subscription paper (copy), 20 July 1861, Woods Administrative Records (1.2.4).

${ }^{74}$ George Evans to Leonard Woods Jr., 26 July 1861, Woods Administrative Records (1.2.4).
} 
On the same day Evans was sharing his concerns about Shepley with Woods, Redfield was writing Shepley to express his own views. "It has within the last few hours been suggested to me by some who feel an interest in the question of establishing a Law Department in Bowdoin College, that it would probably greatly facilitate the action of the two Boards, at the next commencement, if my views could be laid before them in some definite form. I have therefore consented to make a brief statement." Redfield tried to reassure Shepley that "[p]ersonally I feel very little anxiety about the matter," but he cautioned that the plan "should not be undertaken unless there is such a decided feeling in favor of it, among the friends of the college, and the people, \& especially the profession, generally in the state, as to justify the belief that they will give at the least $\$ 25$,ooo. to endow a professorship of Law, so as always to secure the services of one competent resident professor; and also that some reasonable number of pupils might fairly be counted upon." He announced that he felt "great reluctance to be counted a candidate for the office of resident Law Professor, unless there was entire unanimity in both boards in regard to the personal question" of financial support and the date and timing of his availability for appointment. And he warned that "I think the fund to pay $\$ 1500$. [in salary] will best be secured before any attempt is made to start the school. My views are so settled on that point that I should not be willing to begin the Law School proper before that is secured." 75

With all this in mind, the governing boards met two weeks later, in August. They voted that it was "desirable that the Law Department established by Vote of the Boards in $185^{\circ}$, shall go into operation, as soon as a foundation of twenty five

\footnotetext{
${ }^{75}$ Isaac Redfield to Ether Shepley, 26 July 1861, Woods Administrative Records (1.2.4). Redfield was apparently responding in part to a visit at his Boston office on 26 July from Thomas Upham, Professor of Mental and Moral Philosophy at Bowdoin, who suggested the course of action. Isaac Redfield to Rev. Dr. [Alvah?] Hovey, 26 July 1861, Woods Administrative Records (1.2.4). It is difficult to know whether Woods had delegated the task to Upham. On Upham, see Hatch, History of Bowdoin, pp. $5^{8-60}$. One of the factors prompting Redfield's resignation from the bench in Vermont was his "modest" salary (Gold, "Redfield, Railroads, and the Roots of 'Laissez-Faire' Constitutionalism," p. 257).
} 
thousand dollars is secured to the satisfaction of the Financial Committee." If the money were raised, "the President, Judge Shepley and Mr. Evans, [should] be a Committee with such as the Overseers may join to secure the services of Hon. Isaac F. Redfield or other suitable person in that department, and to make such arrangements as may be necessary for the opening of the School." $7^{6}$ There is no evidence that the $\$ 25$, ooo fund was ever raised, and neither Redfield nor any "other suitable person" ever assumed the chair of law professor at Bowdoin. ${ }^{77}$

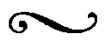

The question remains: why did the plans for a law school at Bowdoin collapse? Certainly Greenleaf's reluctance to head the law department at Bowdoin, despite the president's best efforts, should have given Woods pause. Surely the law schools at Harvard and Yale cast a long shadow, but neither was especially vigorous at this point. After the departures of Story and Greenleaf, Harvard in particular was in a period of decline that would not reverse itself until Langdell's deanship began in 1870 . The number of lawyers continued to increase at midcentury, but perhaps the relative isolation of Brunswick contributed to Bowdoin's difficulty. Money was clearly a problem. Small colleges were always scrambling to raise funds, and there were certainly costs of starting up a new program before tuition dollars could be generated to support a law professor's salary. For all of Greenleaf's and Tenney's complaints about the woeful and rapidly declining status of the bar in Maine, practically none of the state's established public figures, lawyers and nonlawyers alike, pledged funds to underwrite the enterprise. And in 1859, one of the central motives for Greenleaf's plan had been addressed when the Maine legislature abolished the open admissions policy of the bar and created a screening

\footnotetext{
${ }^{76}$ Board of Trustees, Votes and Records (1.1), 7 August 1861, Bowdoin College Archives.

77The law school at Bowdoin disappeared as well from the official histories of the college, last memorialized near the end of the nineteenth century in the General Catalogue (1894), p. lxxxii.
} 
system that approved candidates for the practice of law not only on the basis of their moral character but of their legal knowledge as well..$^{8}$

As the nineteenth century unfolded, more and more colleges were deemphasizing their denominational roots and affiliations. Students, called upon to make their way in an increasingly secular world, were seeking a professional education. Perhaps there was little demand for the type of legal training one small New England college proposed, particularly when a less costly education could be had in law offices, which offered in theory a first-hand look at the "real" world, or when a more "scientific" schooling could be had at places like Harvard, which organized the law into categories that attempted to make sense of the emerging, interconnected, bustling world of markets as well as of the intricacies and problems of the nation-state.

The barriers to the realization of Greenleaf's views on legal education may well have involved more than the difficulty of raising money. The problems may have been conceptual, stemming from certain tensions in Greenleaf's thought: tensions every bit as critical as those he identified between God and Mammon, or between faith in sovereignty residing in the people and distrust of the excesses of public sentiment expressed in law. This friction could derive from choosing to locate authority in the people rather than in the eternal truths revealed by God, a conflict between reason and revelation, or as some might describe it, between positivism and natural law. Greenleaf resolved the dilemma by seeing reason in the timeless truths, a natural, scientific discovery of God's will in a Christian republic. He believed faith should be the organizing principle of a law school devoted to improving the moral quality of the legal profession.

It is difficult to know, of course, how Greenleaf's ideas would have been received had the law school at Bowdoin he helped conceptualize ever opened; on the other hand, it is possible

\footnotetext{
${ }^{78}$ Maine Revised Statutes, chap. 121 (1859), which authorized the Supreme Judicial Court to appoint annually a committee in each county to examine applicants for bar admission.
} 
that the plans he offered were never embraced because, even in evangelically empathetic environments, they were deemed, no matter how attractive, not likely to succeed. Ultimately those principles Greenleaf held so dear were on the wrong side of history. His insights about moral science as an animating force in legal education were abandoned or, at the very least, recast. In its place was substituted a world not of faith but of policy, a world now of prediction not restriction.

Alfred S. Konefsky is a University at Buffalo Distinguished Professor who teaches at SUNY Buffalo Law School, The State University of New York. His work on Simon Greenleaf has been supported by fellowships from the Guggenheim Foundation, the National Endowment for the Humanities, and the American Bar Foundation. He was previously the editor of the multivolume Legal Papers of Daniel Webster. 